\title{
Time to start of cardiopulmonary resuscitation and the effect of target temperature management at $33^{\circ} \mathrm{C}$ and $36^{\circ} \mathrm{C}$
}

\author{
J Dankiewicz ${ }^{*}$, T Cronberg ${ }^{2}$, D Erlinge ${ }^{3}$, H Friberg ${ }^{1}, \mathrm{C} \mathrm{Hassager}^{4}$, J Horn ${ }^{5}$, J Hovdenes ${ }^{6}$, J Kjaergaard ${ }^{4}$, M Kuiper ${ }^{7}$, \\ Y Gasche ${ }^{8}$, T Pellis ${ }^{9}$, P Stammet ${ }^{10}$, M Wanscher ${ }^{4}$, J Wetterslev ${ }^{11}$, MP Wise ${ }^{12}$, A Åneman ${ }^{13}$, N Nielsen ${ }^{14}$
}

From ESICM LIVES 2015

Berlin, Germany. 3-7 October 2015

\section{Introduction}

The optimal target temperature for comatose patients resuscitated from out of hospital cardiac arrest is unknown. It has been hypothesized that patients with long no-flow times, for example those without bystander CPR would have the most to gain from temperature management at lower temperatures [1]. The generalizability of the TTM-trial [2] has been questioned because of a high fraction of patients receiving bystander cardiopulmonary resuscitation (CPR) (73\%) and a median start of basic life support (for patients with bystander CPR) of 1 minute (Interquartile range 1-2 minutes).

\section{Objectives}

The aim of this study was to explore any potential interaction between temperature and no-flow time to investigate whether patients who had longer periods of cerebral ischemia had a better response to the lower target temperature of $33^{\circ} \mathrm{C}$ in the TTM-trial [2].

\section{Methods}

We analysed data from an international clinical trial randomizing cardiac arrest patients to targeted temperature management at $33^{\circ} \mathrm{C}$ and $36^{\circ} \mathrm{C}$ for an interaction between no-flow time and intervention group, with neurological function at 180 days after cardiac arrest as the primary outcome. A cerebral performance category (CPC) score of 1 or 2 was considered a good outcome. The interaction term was included in a multivariate logistic model adjusting for design variables in the TTM-trial.

'Skåne University Hospital, Department of Anesthesiology and Intensive Care, Lund, Sweden

Full list of author information is available at the end of the article

\section{Results}

The interaction between no-flow time and temperature group was not significant. Adjusted predictions showed no difference in the probability of a good neurological outcome for any value of no-flow time (Fig 1). In the group of patients with more than eight minutes of no-flow time the difference in the average predicted probability of a poor outcome was $-0.018(95 \% \mathrm{CI}-0.17-0.13, \mathrm{p}=0.81)$ i.e. a non-significant decrease of $1.8 \%$ in the probability of a poor neurological outcome for patients treated at $36^{\circ} \mathrm{C}$.

\section{Conclusions}

The neutral effect of the two temperature levels was consistent for all no-flow times.

The hypothesis that the efficacy of target temperature at $33^{\circ} \mathrm{C}$ vs. $36^{\circ} \mathrm{C}$ is influenced by no-flow time could not be supported.

\section{Grant Acknowledgment}

Supported by independent research grants from the Swedish Heart-Lung Foundation, Arbetsmarknadens Försäkringsaktiebolag Insurance Foundation, Swedish Research Council, Region Skåne (Sweden), Skåne University Hospital, TrygFonden (Denmark), and European Clinical Research Infrastructures Network.

\footnotetext{
Authors' details

'Skåne University Hospital, Department of Anesthesiology and Intensive Care, Lund, Sweden. 'Skåne University Hospital, Department of Neurology, Lund, Sweden. ${ }^{3}$ Skåne University Hospital, Department of Cardiology, Lund, Sweden. ${ }^{4}$ The Heart Center, Copenhagen University Hospital, Copenhagen, Denmark. ${ }^{5}$ Academic Medical Centre, Department of Intensive Care, Amsterdam, Netherlands. ${ }^{6}$ Rikshospitalet, Oslo University Hospital, Department of Anesthesiology, Oslo, Norway. ${ }^{7}$ Department of Intensive Care, Leeuwarden Hospital, Leeuwarden, Netherlands. ${ }^{8}$ Geneva University Hospital, Department of Intensive Care, Geneva, Switzerland. ${ }^{9}$ Santa Maria degli
} 

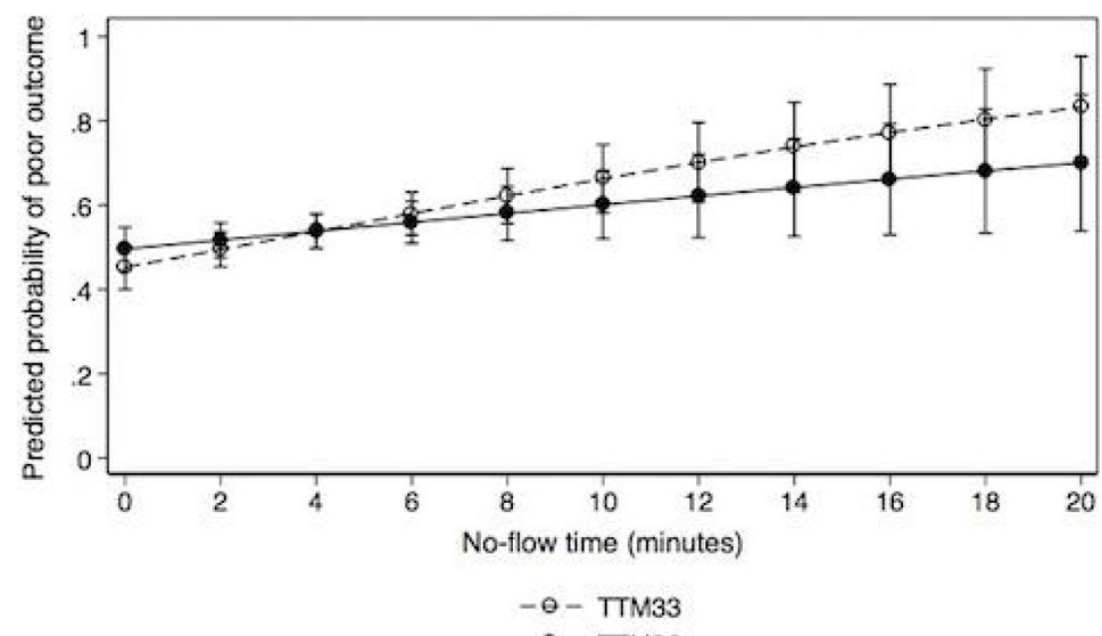

Figure 1

Ángeli, Department of Intensive Care, Pordenone, Italy. ${ }^{10}$ Centre Hospitalier de Luxembourg, Department of Anesthesiology and Intensive Care, Luxembourg, Luxembourg. ${ }^{11}$ Copenhagen Trial Unit, Copenhagen, Denmark.

${ }^{12}$ University Hospital of Wales, Adult Critical Care, Cardiff, United Kingdom.

${ }^{13}$ Liverpool Hospital, Department of Intensive Care, Sydney, Australia.

${ }^{14}$ Helsingborg Hospital, Department of Anesthesiology and Intensive Care, Helsingborg, Sweden.

Published: 1 October 2015

\section{References}

1. Testori $C$, et al: The beneficial effect of mild therapeutic hypothermia depends on the time of complete circulatory standstill in patients with cardiac arrest. Resuscitation 2012, 83(5):596-601.

2. Nielsen $\mathrm{N}$, et al: Targeted Temperature Management at $33^{\circ} \mathrm{C}$ versus $36^{\circ} \mathrm{C}$ after Cardiac Arrest. New England Journal of Medicine 2013.

doi:10.1186/2197-425X-3-S1-A844

Cite this article as: Dankiewicz et al:: Time to start of cardiopulmonary resuscitation and the effect of target temperature management at $33^{\circ} \mathrm{C}$ and $36^{\circ} \mathrm{C}$. Intensive Care Medicine Experimental 2015 3(Suppl 1):A844.

\section{Submit your manuscript to a SpringerOpen ${ }^{\circ}$ journal and benefit from:}

- Convenient online submission

- Rigorous peer review

- Immediate publication on acceptance

- Open access: articles freely available online

- High visibility within the field

- Retaining the copyright to your article

Submit your next manuscript at $\boldsymbol{s p r i n g e r o p e n . c o m ~}$ 